\title{
Numerical modeling as a basic tool for evaluation of using mine water as a heat source
}

\author{
J. Baier ${ }^{1}$, M. Polák ${ }^{1}$, M. Šindeláŕ ${ }^{2} \&$ J. Uhlík ${ }^{1}$ \\ ${ }^{1}$ ProGeo s.r.o., Czech Republic \\ ${ }^{2}$ ARCADIS geotechnika a.s., Czech Republic
}

\begin{abstract}
In 2007 research on the possibilities of using mine water as a heat source started. Major research goals were: a) model evaluation of the heat transfer in the rock containing selected mines; b) model prediction of the temperature change due to the heat pump operation.

A database containing data from abandoned mines covering the Czech Republic area was created. It contains mine water volumes, chemical parameters and temperatures.

Two types of simulation software were used. For the Plzeňská basin region the heat transfer and groundwater flow were calculated using MODFLOW and MT3DMS simulation software. Their numerical code is based on the finite difference method (FDM). For the Prríbram region the FEFLOW code was used. FEFLOW numerical code is based on the finite element method (FEM).

Model results show that the mining water temperature decrease due to the groundwater abstraction for the heat pump will be relatively small. Temperature decrease originates from the fact that colder shallow groundwater will inflow into mine spaces mixing with the warmer mine water. The time scale of the mine water temperature decrease is over several centuries. The temperature conditions of the mine water could be very stable. Abandoned mines are supposed to be a suitable geothermal energy source.
\end{abstract}

Keywords: numerical modeling, FEFLOW, MODFLOW, MT3DMS, abandoned mine, mine water, heat pump, geothermal energy. 


\section{Introduction and background}

As mentioned by several authors (Myslil et al. [3], Renz et al. [6]) the geothermal energy is one of the most ecologically friendly and economically optimal methods of energy production. In contrast to the other alternative energy resources (wind, water, solar) the heat pump installation has minimal influence on the landscape character. Exploitation of geothermal energy from abandoned flooded mines can be a very suitable energy source even in natural protected areas. Due to mining the extensive fracture systems were developed. These allow the groundwater to flow through the relatively impermeable rock formations, where groundwater pumping from the installed boreholes would not yield a certain amount of groundwater.

In the Czech Republic there are approximately 12-15 thousand mining localities. The estimated amount of mine water in abandoned and consequently flooded mines is 13-15 million cubic meters. The project called "The research on utilization of energetic potential of mine water from the former mining sites in Czech Republic" started in the year 2007. At the beginning of the research project the data about mine workings, their reinsurance, technical parameters, hydrogeology conditions and mine water physical and chemical parameters were collected. Consequently, according to the established criteria two representative localities of coal and uranium mines near the Plzeň and Př́bram cities were chosen (Fig. 1). An important part of the research was to evaluate the possibilities of numerical modelling of groundwater flow and heat transfer in flooded mines, and through the use of the models assess the influence of mine water abstraction on the regional and local hydro geological regimes and on the temperature field.

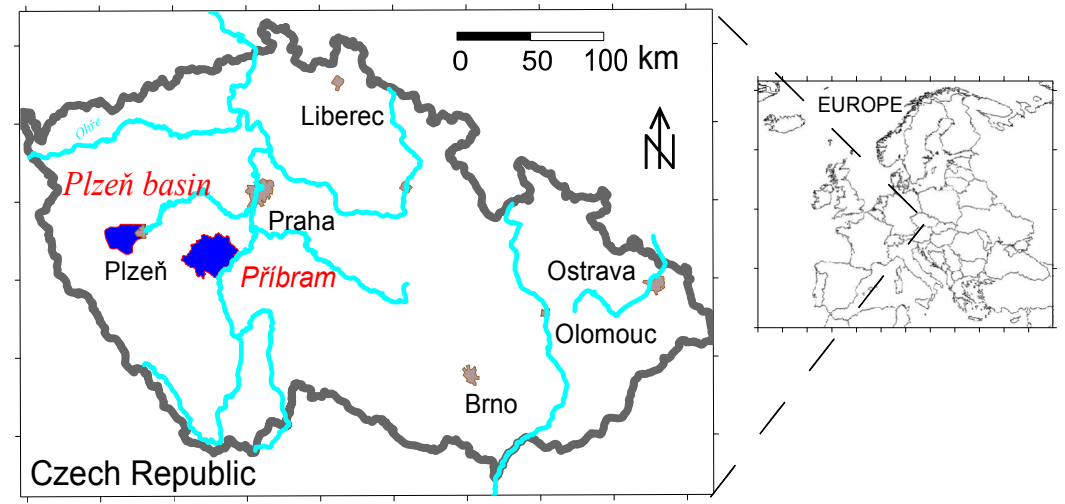

Figure 1: $\quad$ Study areas - Plzeň basin and Př́ibram mine workings area.

There are several CFD mathematical models (fluent, Flow-3D) which are powerful tools for the computing of the temperature field in the fluid environment as well as useful tools for simulating local temperature distribution in mines and their surroundings. The problem arises when evaluation of the influence of groundwater abstraction on the regional hydrogeological conditions is needed. On this regional scale it is necessary to take into account the drainage 
into the streams, infiltration, preferential flow, etc. For our regional scale model of the Plzeňska basin programs MODFLOW (Hill et al. [1]) and MT3DMS (Zheng and Wang [12]) were used to simulate groundwater flow and heat transfer. The MT3DMS application for heat transport modelling is based on the similarity between the Fick and Fourier's Law, describing heat and solute transport (Thorne et al. [10,11]). Unlike in the case of the solute transport, where movement is essentially confined to the fluid phases, energy is also transported through the aquifer solids by the conduction (controlled by the thermal conductivity of the solids). Hence, the new parameters $\mathrm{k}_{\text {Tfluid }}$ and $\mathrm{k}_{\text {Tsolid }}$ are considered in order to distinguish the thermal conductivities of the fluid and solid phases. The FEFLOW (Diersch [2]) software was used for regional groundwater flow and heat transport simulation in the uranium mine area near the Příbram. In contrast with the MT3DMS software, the FEFLOW has been authentically developed for heat simulation, and it has already been used for simulating groundwater flow and heat transfer in mine regions by several authors (Rapantova et al. [6], Renz et al. [7]).

\section{Numerical models application}

\subsection{Case study: groundwater flow and heat transfer modelling in the southern part of the Plzeňská basin}

The main goals were: a) to verify MT3DMS possibilities for heat transfer and groundwater flow simulation; b) to determine the impact of mine water abstraction on the local and regional hydrogeological conditions c) to evaluate abstracted mine water temperature development during the long running operation of the heat pump.

Realized simulations of groundwater flow, heat transfer and their purposes are shown in the Table 1.

Table 1: $\quad$ The simulation variants.

\begin{tabular}{|c|c|c|}
\hline $\begin{array}{c}\text { Groundwater flow } \\
\text { simulations }\end{array}$ & Heat transfer simulations & Simulation purpose \\
\hline $\begin{array}{c}\text { Variant 1: Steady state } \\
\text { groundwater flow simulation } \\
\text { with extraction from mine }\end{array}$ & -- & $\begin{array}{c}\text { Hydraulic parameters calibration } \\
\text { based on comparing observed and } \\
\text { computed hydraulic heads and } \\
\text { streams flow rates }\end{array}$ \\
\hline $\begin{array}{c}\text { Variant 2: Steady state } \\
\text { groundwater flow simulation } \\
\text { without extraction from mines }\end{array}$ & $\begin{array}{c}\text { Heat transfer simulation without } \\
\text { groundwater extraction }\end{array}$ & $\begin{array}{c}\text { Groundwater flow and heat transfer } \\
\text { simulations under present } \\
\text { conditions }\end{array}$ \\
\hline $\begin{array}{c}\text { Variant 3: Steady state } \\
\text { groundwater flow simulation } \\
\text { with groundwater extraction of } \\
201 / \mathrm{s} \text { for heat pump }\end{array}$ & $\begin{array}{c}\text { Heat transfer simulation - } \\
\text { groundwater extraction } 20 \mathrm{l} / \mathrm{s}\end{array}$ & $\begin{array}{c}\text { Groundwater flow and heat transfer } \\
\text { prognosis simulation }\end{array}$ \\
\hline $\begin{array}{c}\text { Variant 4: Steady state } \\
\text { groundwater flow simulation } \\
\text { with groundwater extraction of } \\
40 \mathrm{l} / \mathrm{s} \text { for heat pump }\end{array}$ & $\begin{array}{c}\text { Heat transfer simulation - } \\
\text { groundwater extraction } 40 \mathrm{l} / \mathrm{s}\end{array}$ & $\begin{array}{c}\text { Groundwater flow and heat transfer } \\
\text { prognosis simulation }\end{array}$ \\
\hline
\end{tabular}

\subsubsection{Brief characterization of study area}

Collectors and isolators alternation is characteristic for vertical profile of the Plzeňská basin. The basin is formed by kladno, týnec, slaný and lín strata 
composed of sandstones, arkoses, siltstones and claystones sediments. During the mine operation a significant part of groundwater flow took place in a vertical direction. Proterozoic strata below the Plzeňská basin sediments are impermeable.

Hydraulic properties give Švoma et al. [9]. The average transmissivity of carbon collectors to the depth of $150 \mathrm{~m}$ is in the range from $* 10^{-5}$ to $\mathrm{n}^{*} 10^{-4} \mathrm{~m}^{2} \mathrm{~s}^{-1}$. The bottom layer transmissivity decreases to $9.10^{-6} \mathrm{~m}^{2} \mathrm{~s}^{-1}$. The whole area of Plzeňská basin is recharged by the rain infiltration. The collectors are mainly under confined conditions. During operations time the groundwater abstraction of tenths liters existed from every bigger mine. Piezometric head in the basin dropped, resulting into zero groundwater drainage into many reaches of local streams.

\subsubsection{Groundwater flow simulations}

The model area of the Plzenska basin is discretized by the rectangular mesh. The size of every model cell is $200 \times 200 \mathrm{~m}$. In the vertical direction carbon sediments are divided into 5 layers. Top of the first layer represent surface and the bottom of the fifth layer corresponds with Plzeňská basin bottom. The Cauchy boundary condition was selected to simulate drainage in to the surface streams. Neumann boundary condition has been used for abstraction wells and recharge simulation. The infiltration rate is set up in the range between 0.6$2.0 \mathrm{ls}^{-1} \mathrm{~km}^{-2}$ with dependency on surface cover and altitude. Abstraction rates depend on the actual model variant. The model calibration was carried out comparing model and measured groundwater levels and comparing simulated and evaluated stream drainage.

\subsubsection{Groundwater flow simulations results}

Variant 2 describes actual flow condition after all mines are abandoned and flooded. Without mine pumping, the piezometric heads change only slightly in the vertical. Fresh groundwater circulation exists only near the ground surface. At the bottom of the basin the groundwater flow is negligible.

Two different groundwater extractions (25 and $40 \mathrm{l} / \mathrm{s}$ ) were simulated to mimic heat pump operation. It allowed us to analyze: a) the regional and local hydraulic impact with respect to the pumped amount; b) temperature field deformation with respect to the pumping amount. The groundwater abstraction occurs in the 4th model layer containing mine galleries. Hydraulic effect of the mine space is simulated via extremely high hydraulic conductivity values. Under this setup, the hydraulic depression occurs preferentially in the mine space. Mine water preferentially flows to the abstraction place. The model results can be summed up into several points below:

- $\quad$ piezometric head in the interconnected mine space is almost the same,

- $\quad$ steep piezometric gradient (Fig. 2) is taking place in the rock environment without mine space,

- $\quad$ higher mine water abstraction for the heat pump will cause piezometric head drawdown about of $160 \mathrm{~m}$ (Fig. 2). 


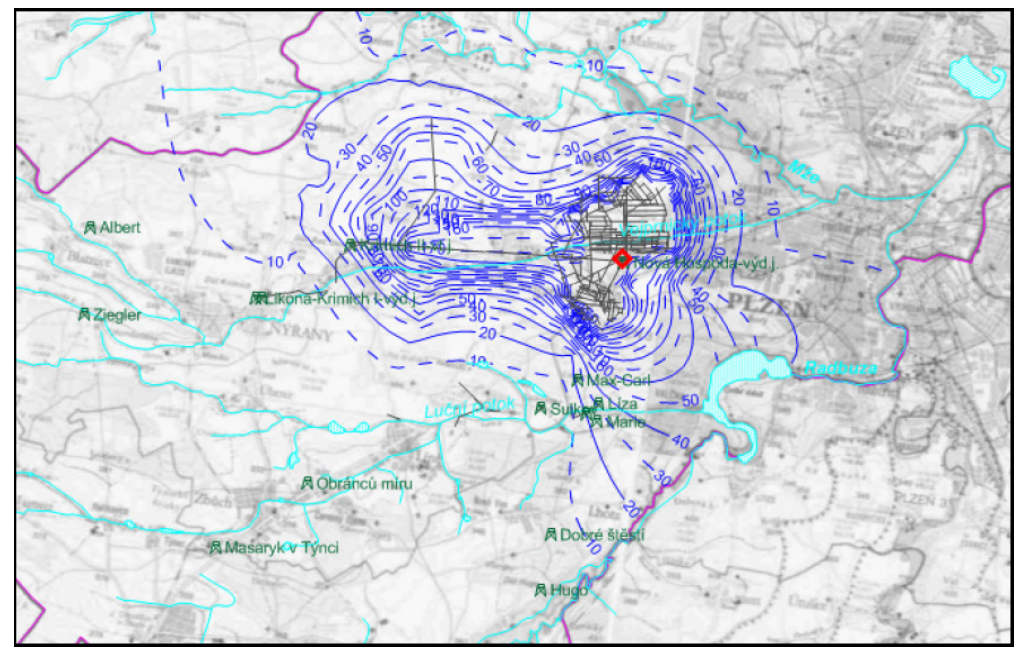

Figure 2: $\quad$ Variant 4 - simulated groundwater drawdown (in metres) caused by $40 \mathrm{l} / \mathrm{s}$ groundwater abstraction for heat pump.

\subsubsection{Heat transfer simulations}

Heat transfer numerical modelling requires special sets of input information, like the initial groundwater temperature, thermal conductivity and capacity, terrestrial heat flow across the basin bottom, etc. In the Czech Republic there has not been stressed the measuring of those yet, hence in most cases the parameter values had to be established from tabular data.

Finally the model thermal conductivity was set $1.96 \mathrm{~W} \mathrm{~m}^{-1} .{ }^{\circ} \mathrm{C}^{-1}$ for first layer and $2.12 \mathrm{~W} \mathrm{~m}^{-1} .{ }^{\circ} \mathrm{C}^{-1}$ for second to fifth model layer. While keeping a fixed temperature of $9.5^{\circ} \mathrm{C}$ at the top model layer, a constant heat flux of $60 \mathrm{~mW} \mathrm{~m}{ }^{-2}$ was defined for the bottom layer. Under this condition without mine water extraction the initial conditions were computed for variant 3 and 4 . According to the model results highest temperature occurs in the fifth model layer (Fig. 3).

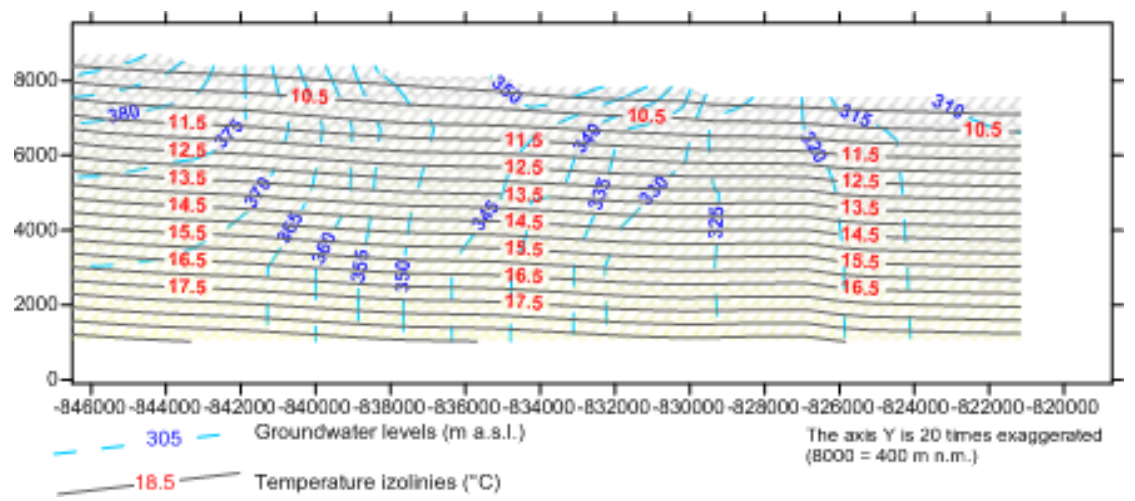

Figure 3: Variant 2 - simulated vertical temperature and piezometric heads distribution. 
The highest bottom layer temperature (almost $20^{\circ} \mathrm{C}$ ) coincides with the highest vertical thickness of saturated rock. The average groundwater temperature in the bottom layer equals $18.73^{\circ} \mathrm{C}$. The average difference in temperature between the 1 st and 5 th layer is $9.23^{\circ} \mathrm{C}$. In the Nová Hospoda (extraction place for heat pump) the temperature gradient $1{ }^{\circ} \mathrm{C} / 35$ meters exists.

Mine water extraction for the heat pump will accelerate groundwater inflow into the mine spaces (Fig. 4).

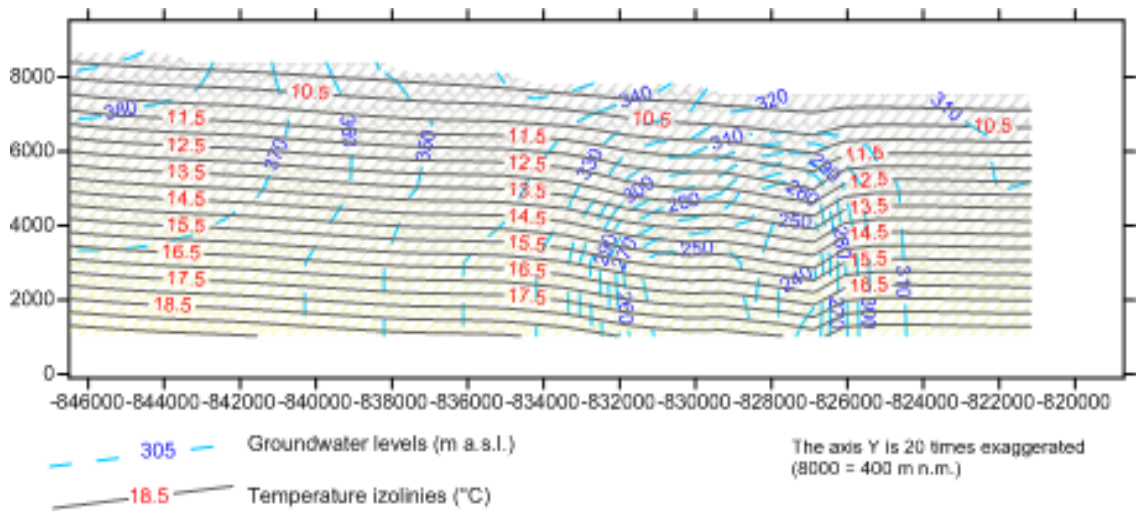

Figure 4: Variant 3 - simulated vertical temperature and piezometric heads distribution.

Downward groundwater flow gradient is established. Cooler groundwater from near the surface flows into the mine. The temperature field is altered and in the areas where the flow direction was changed the decrease of groundwater and rock temperature can be examined. The affected area with temperature drop is $5 \mathrm{~km}^{2}$ or $8 \mathrm{~km}^{2}$, depending on the heat pump mine water extraction ( 20 or $40 \mathrm{l} / \mathrm{s}$ ). Predicted and stabilized temperature decrease for $20 \mathrm{l} / \mathrm{s}$ or $40 \mathrm{l} / \mathrm{s}$ extraction rates are in range $0-1^{\circ} \mathrm{C}$ or $0-2^{\circ} \mathrm{C}$ (Fig 4$)$.

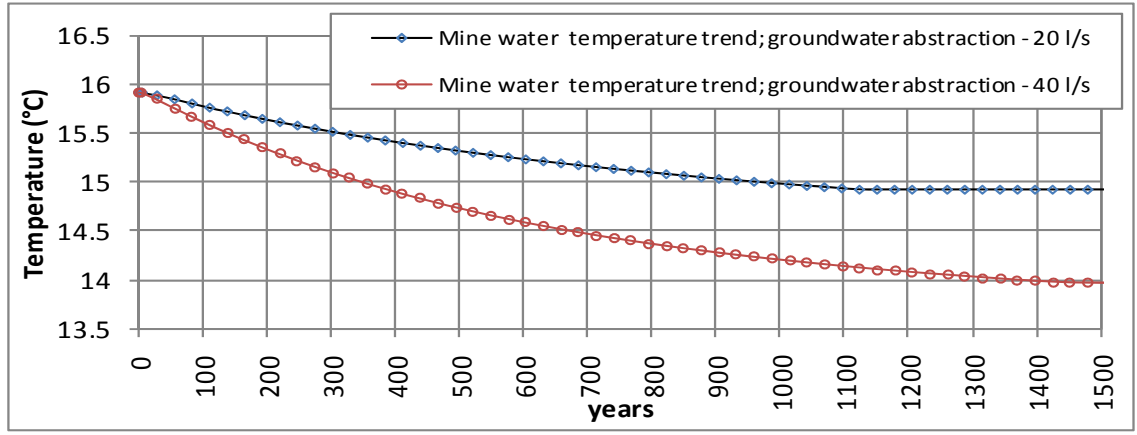

Figure 5: Variant 3,4- simulated groundwater temperature change in the extraction place. 


\subsection{Case study: groundwater flow and heat transfer modelling in the Př́bram region}

Simulation goals were: a) to set and calibrate regional groundwater flow and heat transfer model; b) to determinate thermo-dynamical and hydraulic regimes affection by the mine workings; c) to evaluate affection of present hydraulic regime by the groundwater abstraction for heat pump; d) verification of FEFLOW code possibilities to simulate heat and groundwater flow in the rock with the abandoned uranium mine.

Table 2: $\quad$ Model variants and purposes.

\begin{tabular}{|c|c|}
\hline $\begin{array}{c}\text { Groundwater flow and heat transfer simulation } \\
\text { variant }\end{array}$ & Simulation purpose \\
\hline $\begin{array}{c}\text { Variant 1:steady state simulation while conditions } \\
\text { affected by mining and mine water abstraction - } \\
\text { present time }\end{array}$ & $\begin{array}{c}\text { Model calibration based on comparing hydraulic head, } \\
\text { simulation of hydrogeological condition after flooded } \\
\text { mines - present time }\end{array}$ \\
\hline $\begin{array}{c}\text { Variant 2: steady state simulation while condition } \\
\text { unaffected by mining }\end{array}$ & $\begin{array}{c}\text { Simulation of supposed state before mining was started } \\
\text { (ideal historical state) }\end{array}$ \\
\hline $\begin{array}{l}\text { Variant 3: steady state simulation while mine water } \\
\text { abstraction for heat pump }(25 \mathrm{l} / \mathrm{s}) \text { from colliery } \\
\text { Marie }\end{array}$ & $\begin{array}{l}\text { Groundwater flow and heat transfer prognosis simulation, } \\
\text { affected temperature field by groundwater abstraction }\end{array}$ \\
\hline $\begin{array}{l}\text { Variant 4: steady state simulation while mine water } \\
\text { abstraction for heat pump }(25 \mathrm{l} / \mathrm{s}) \text { from colliery } 15\end{array}$ & $\begin{array}{l}\text { Groundwater flow and heat transfer prognosis simulation, } \\
\text { affected temperature field by groundwater abstraction }\end{array}$ \\
\hline
\end{tabular}

\subsubsection{Brief characterization of the study area}

The underground exploitation of the polymetallic deposit started in the 14th century. In the $20^{\text {th }}$ century uranium ore was the only exploited mineral. In 1991 all the mining works stopped. Groundwater flows primarily in the areas close to the surface or through fracture system reaching also the depth of uranium mine. The phreatic groundwater level mostly conform to the ground surface. Hydraulic conductivities vary over 4 orders of magnitude.

Table 3: Horizontal conductivity range.

\begin{tabular}{|c|c|c|}
\hline litologicko-stratifrafický typ & max. k (m/s) & min. $\mathbf{~ k ~ ( m / s ) ~}$ \\
\hline Cambrian shale and agglomerate & $5.00 \mathrm{E}-06$ & $5.41 \mathrm{E}-10$ \\
\hline Nonproteozoic shale and wacke & $2.50 \mathrm{E}-06$ & $2.70 \mathrm{E}-10$ \\
\hline Varis granitoids & $5.00 \mathrm{E}-07$ & $5.41 \mathrm{E}-11$ \\
\hline Bazalts and metabazalts & $2.50 \mathrm{E}-06$ & $2.70 \mathrm{E}-10$ \\
\hline
\end{tabular}

\subsubsection{Groundwater flow simulations setup}

Irregular triangle mesh, built up from 39065 linear elements, covers the regional model area. In the vertical direction the rock environment is divided into the 13 model layers. The first model layer is near the terrain. The bottom of the model is $1400 \mathrm{~m}$ b.s.l. The drainage/infiltration in/out of the streams was set by Newton boundary condition (fourth kind) where the flux across the boundary depends on a piezometric head in each compute node. Constant flux (Neumann boundary condition) of intensity $2-7 \mathrm{l} / \mathrm{s} / \mathrm{km}^{2}$ was set up at the top of the model, representing rain infiltration. The remaining model boundaries have zero flux defined across them. Mine water extraction for the heat pump is simulated using multi-layer well method. It is supposed that the fracture permeability decrease 
with the depths in the model. The area affected by mining activities is represented by higher hydraulic conductivity and porosity zones in the model. Hydraulic conductivity estimation of the elements representing mine space was a significant part of the model calibration.

\subsubsection{Groundwater flow simulations results}

Model calibration was carried out simulating the variant 1 (Table 2). We had enough piezometric heads, temperatures and mine inflow data from time of mine operation. Regional groundwater flow takes place mostly in the west-east direction - from the central spine of Brdy upland to the Vltava river (Fig. 6). According to model results mine areas act as preferential pathways for groundwater flow.

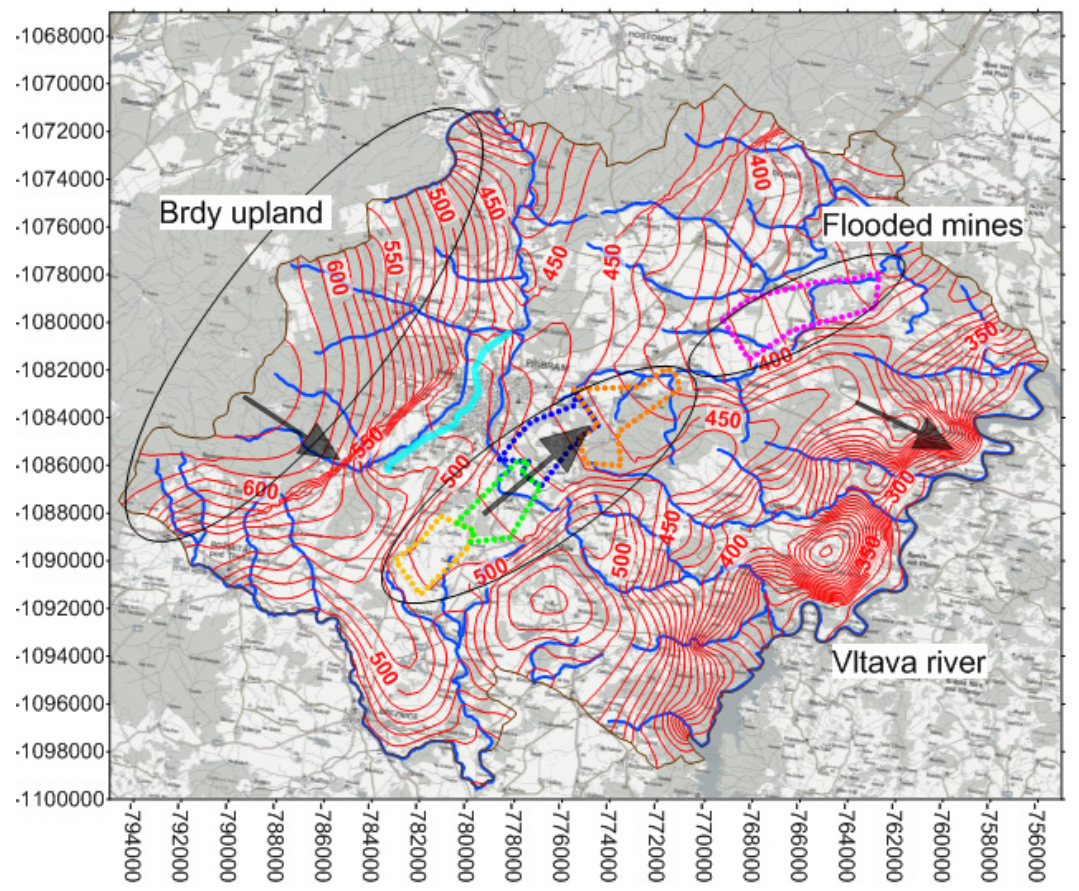

Figure 6: Variant $1-$ simulated groundwater levels (fifth model slice).

\subsubsection{Heat transfer simulation description and results}

Natural temperature field of the model domain (variant 2) was simulated having: bottom constant heat flux $50 \mathrm{~mW} \mathrm{~m}^{-2}$; first model layer at constant temperature $10^{\circ} \mathrm{C}$; zero heat flux across remaining boundaries; thermal conductivity in the range of $2-3 \mathrm{~W} \cdot \mathrm{m}^{-1} \cdot \mathrm{K}^{-1}$; the specific heat capacity in the range of 2600 $3000 \mathrm{~J} \mathrm{~kg}^{-1} \mathrm{~K}^{-1}$. The groundwater temperature rises fluently from the surface down to the model bottom (- $1400 \mathrm{~m}$ a. s. 1.), where the temperature values are in a range of $35-42^{\circ} \mathrm{C}$. These values are in the satisfactory agreement with measured mine water temperature from the deepest colliery. 
At present time (variant 1) the lowest temperature in the bottom layer is in the model domain between the colliery 16 and 19 in the place with groundwater extraction (Fig. 7). The amount of groundwater flowing from surface to the model bottom has risen and the flow has become deeper comparing to situation without mines. The colder water flow from upper layers is mixing with the warmer water at the mine attitude causing the decrease of saturated rock temperature. Former mine water abstraction during the mine operation period and present mine water abstraction for cleaning purposes causes rock within the mine to become colder.

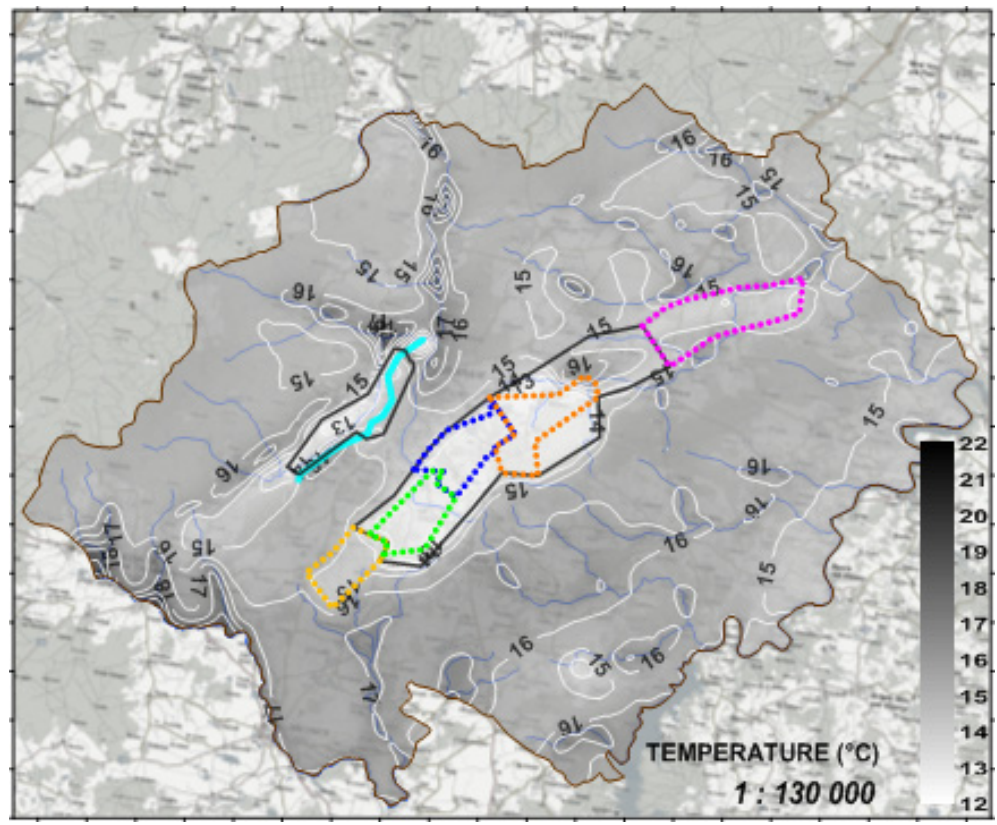

Figure 7: Variant $1-$ simulated horizontal temperature distribution.

The groundwater abstraction $25 \mathrm{l} / \mathrm{s}$ for heat pump is taking a place in colliery Marie in variant 3 or in colliery 15 for variant 4 . The final vertical temperature field distribution for variant 4 is presented in Figure 8 .

The groundwater abstraction was simulated via multi-layer well method in the depth 50 to $-100 \mathrm{~m}$ a. s. 1 from layers 7, 8 and 9. The groundwater flow abstraction was also simulated via multi-layer well method. But in this case not in the whole vertical line in colliery 15 (like in variant 3 ) but only in three layers $(7,8,9)$ in order to test possibilities of simulating concrete deep of abstraction and to define effect of perforated intervals of abstraction system in the colliery.

Model results show a slight temperature increase in the colliery under the abstraction place (Fig. 9(b)). In the deeper colliery part below abstraction depth upward groundwater flow is activated.

The abstraction place and upper colliery part become colder. Downward groundwater flow exists (Figure 9(a)). 
82 Energy and Sustainability III

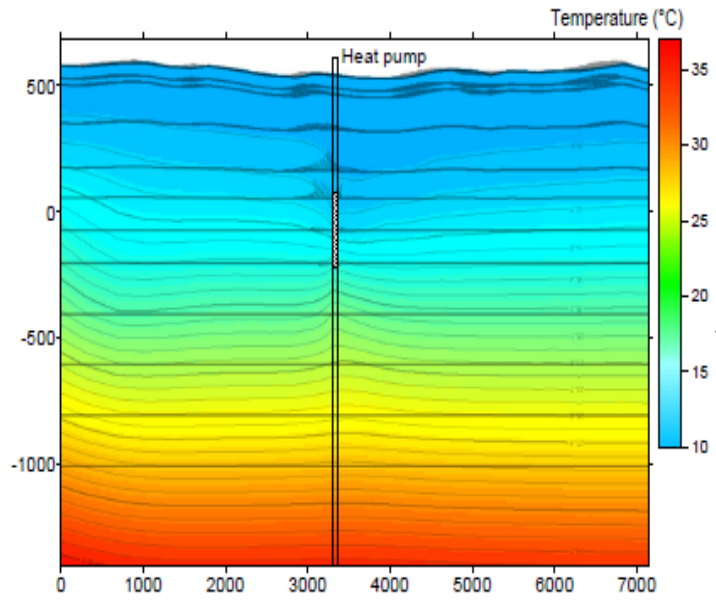

Figure 8: Variant 4 - simulated vertical temperature distribution.
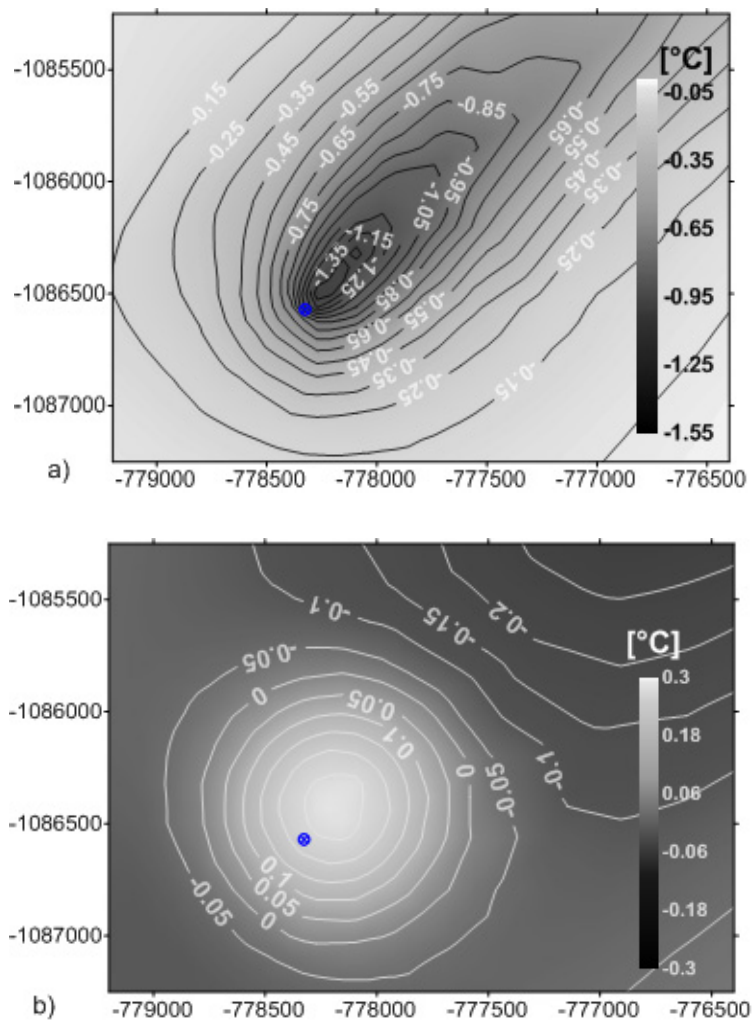

Figure 9: $\quad$ Variant $4-$ simulated temperature changes around the abstracted place in 8th (a) and 12th (b) model slice - comparison with variant 1. 


\section{Discussion}

This paper presents two different approaches to regional groundwater flow and heat transport simulation in the rock with abandoned mines. In the first approach the MODFLOW (Hill et al. [1]) and MT3DMS (Zheng and Wang [12]) software was used. In the second approach the FEFLOW (Diersch [2]) software was used.

Resulting experience can be summarized in the several points: a) even if heat from the mine water is extracted outside the rock (the heat exchanger is not placed directly to the flooded mines), mine water abstraction for the heat pump will cause rock and the pumped water to become colder; b) with MT3DMS it is not possible to take into account temperature and chemistry dependence of groundwater flow resulting into the density dependent flow. Because of forced mine water circulation due to the mine water abstraction these effect could be omitted; c) of key importance is model mine space hydraulics representation. In both, MT3DMS and FEFLOW simulation, mine space hydraulics representation is only approximation. Mine water velocity pattern is of key importance in transport calculation. So the model prediction of the temperature decrease undergoes some uncertainty; d) much bigger uncertainty is connected with the fact that values of terrestrial heat flow, rock thermal conductivity and capacity are often missing. Much more survey on this topic should be performed; e) certain problems with using mine water could be connected with the fact, that the mine water is usually highly mineralized. Incrustation in the heat pump exchanger is anticipated.

\section{Conclusion}

Flooded mines could serve as water source for heat pumps even in low permeable formations. Up to this advantage mines are supposed to be a temperature stable source. Model predicted mine water temperature changes are relatively small. The time scale of the temperature change exceeds human life.

Some disadvantages and limitations of the chosen modelling approaches were found. In further studies, while simulating heat exchanger in the mine space, we want to use SEAWAT (Langevin et al. [3]) model, which allows us to take into account density depend flow. Another improvement could be attained with CPF MODFLOW module (Shoemaker et al. [8]). It enables turbulent or laminar groundwater flow simulation.

Model application allows us to evaluate heat pump hydraulic and temperature influence. The biggest source of uncertainty is connected with the lack of rock thermal properties data.

\section{Acknowledgement}

This project was financially supported from the State Budget of the Ministry of Industry and Trade of the Czech Republic. 


\section{References}

[1] Hill, M.C., Banta, E.R., Harbaugh, A.W., and Anderman, E.R.: MODFLOW-2000, the U.S. Geological Survey modular ground-water model-User guide to the Observation, Sensitivity, and ParameterEstimation Processes and three post-processing programs: U.S. Geological Survey Open-File Report 00-184, 209 p., 2000

[2] Diersch H-JG: FEFLOW finite element subsurface flow and transport simulation system, reference manual, WASY, Institute for Water Resources Planning and Systems Research, Berlin, 292 p., 2005

[3] Langevin, C.D., Thorne, D.T., Jr., Dausman, A.M., Sukop, M.C., and Guo, Weixing, SEAWAT Version4: A Computer Program for Simulation of Multi-Species Solute and Heat Transport: U.S. Geological Survey Techniques and Methods Book 6, Chapter A22, 39 p., 2007

[4] Myslil, V., Kukal, Z., Pošmourný, K., Frydrich, V.: Geotermální energie. Ekologická energie $\mathrm{z}$ hlubin Země - současné možnosti využívání. Planeta, MŽP Praha, roč. 15, č. 4, 32, 2007

[5] Nam Y., Ooka R, Hwang S.: Development of a numerical model too predict heat exchange rates for a ground-source heat pump system, Energy and Buildings 40 (2008) 2133 - 2140, 2007

[6] Rapantova N, Grmela A, Vojtek D, Halir J, Michalek B: Ground water flow modelling applications in mining hydrogeology. Mine Water Environ. doi:10.1007/s10230-007-0017-1, 2007

[7] Renz A, Rühaak W, Schätzl H, Diersh J.: Numerical Modeling of Geothermal Use of Mine Water: Challenges and Examples, Mine water Environ 28:2-14, 2009

[8] Shoemaker B., Kuniansky E., Birk S., Bauer S., and Swain E.: Documentation of a Conduit Flow Process (CFP) for MODFLOW-2005, S. Geological Survey, Reston, Virginia: 2007

[9] Švoma J., et al.; Plzeňská pánev. Regionální hydrogeologický průzkum. Závěrečná zpráva. - MS, Geofond Praha, 1970

[10] Thorne D., Langevin Ch., Sukop C. M.; Addition of simultaneous heat and solute transport and variable fluid viscosity to SEAWAT, Computers \& Geosciences 32,1758 - 1768, 2006

[11] Thorne D, Langevin Ch, Sukop M.: MODFLOW/MT3DMS - Based simulation of variable-density groundwater flow with simultaneous heat and solute transport, XVI International Conference on Computational Methods in Water Resources, Copenhagen, 2006

[12] Zheng, C., and Wang, P.P.: MT3DMS, A modular three-dimensional multispecies transport model for simulation of advection, dispersion and chemical reactions of contaminants in groundwater systems: Vicksburg, Miss., Waterways Experiment Station, U.S. Army Corps of Engineers. 1998 